\title{
PENGARUH GOOD CORPORATE GOVERNANCE, DAN KARAKTERISTIK PERUSAHAAN TERHADAP NILAI PERUSAHAAN
}

\author{
DWI PUTRI KARTIKA SARI \\ RIKI SANJAYA \\ Trisakti School of Management \\ dwiputrikartikasari@yahoo.com riki_sanjaya12@yahoo.com
}

\begin{abstract}
The objective of this research to investigate the influence of good corporate governance and firm's characteristic on firm value as a firm's strategy to upgrade their value. This study use financial statement from non financial firm in Bursa Efek Indonesia for three years, start from 2014 - 2016. This study using purposive sampling method for determine a sample is required and using multiple regression and statistic descriptive for analyze data. The result of this study is four of eight variable independen influence on firm value. Independent commissioner, size of commissioner, Return on Equity, and Leverage as a component of good corporate governance influence firm value. But another good corporate governance's component like managerial ownership, institusional ownership, audit committee, and component of firm's characteristic there is firm size don't effect firm value.
\end{abstract}

Keywords : Good Corporate Governance, Firm's Characteristic and Firm Value.

Abstrak :Tujuan penelitian adalah melihat apakah nilai perusahaan dapat dipengaruhi oleh good corporate governance dan karakteristik dari perusahaan, yang merupakan salah satu strategi perusahaan untuk meningkatkan nilai perusahaan. Penelitian ini menggunakan data laporan keuangan dari perusahaan non keuangan yang terdaftar di Bursa Efek Indonesia selama tiga tahun yaitu 2014-2016. Penelitian ini menggunakan metode purposive sampling untuk menentukan sampel yang dibutuhkan penelitian dan untuk menganalisa data menggunakan regresi berganda dan statitik deskriptif. Hasil dari penelitian terdapat empat dari delapan varibel independen berpengaruh terhadap nilai perusahaan. Variabel dewan komisaris independen, ukuran dewan komisaris, return on equity, dan leverage sebagai komponen good corporate governance mempengaruhi nilai perusahaan. Namun komponen good corporate governance lain seperti kepemilikan managerial, kepemilikan institusional, komite audit dan komponen karakteristik perusahaan yakni ukuran perusahaan tidak mempengaruhi nilai perusahaan.

Kata Kunci : Tata Kelola Perusahaan yang Baik, Karakteristik Perusahaan dan Nilai Perusahaan.

\section{PENDAHULUAN}

Perkembangan globalisasi yang ada di
Indonesia telah mendorong terjadinya
persaingan antar perusahaan dalam
mengembangkan serta mempertahankan diri

dalam pasar. Hal ini menyebabkan dorongan yang sangat kuat terhadap perusahaan untuk berlomba mengadu strategi dalam mengambil hati investor agar mereka tertarik untuk menanamkan modal kepada perusahaan dengan cara meningkatkan nilai perusahaan. 
Nilai perusahaan dapat dicerminkan oleh harga saham perusahaan yang merupakan gambaran keputusan investasi, pembiayaan dan manajemen aset (Debby et al. 2014). Nilai perusahaan merupakan suatu hal yang sangat penting bagi perusahaan karena dengan nilai perusahaan yang tinggi, maka akan diikuti dengan tingginya kemakmuran pemegang saham (Suroto 2015). Tingkat pengembalian yang tinggi mencerminkan kinerja yang baik, sehingga manajer yang baik diperlukan untuk mendapatkan kinerja yang optimal bagi prospek masa depan perusahaan.

Penelitian ini merupakan replikasi sekaligus pengembangan dari penelitian yang dilakukan Debby et al. (2014) yang berjudul Good Corporate Governance, Company's Characteristics and Firm's Value: Empirical Study of Listed Banking on Indonesian Stock Exchange. Dengan menambahkan tiga variabel independen lainnya, tahun penelitian dan obyek penelitian berbeda maka penulis memberikan judul Pengaruh Good Corporate Governace dan Karakteristik Perusahaan terhadap Nilai Perusahaan. Tujuan dari penelitian ini untuk melihat apakah terdapat pengaruh Kepemilikan Managerial, Dewan Komisaris Independen, Ukuran Dewan Komisaris, Komite Audit, Ukuran Perusahaan, Return on equity, Kepemilikan Institusional, dan Leverage terhadap Nilai Perusahaan sebagai variabel dependen.

\section{Teori Keagenan}

Agency Theory adalah hubungan keagenan yang muncul ketika satu atau lebih prinsipal mempekerjakan agen sebagai pihak yang menjalankan perusahaan dan prinsipal memberikan atau mendelegasikan hak kepada agen untuk mengambil keputusan (Jensen dan Meckling 1976). Hubungan keagenan ini muncul karena adanya kesepakatan antara prinsipal (pihak pemegang saham) dan pihak agen (pihak manajemen) untuk melakukan kerjasama. Dalam hal ini maka pihak agen yang bertugas dalam menjalankan perusahaan secara langsung dan hal ini membuat pihak agen lebih mengetahui informasi yang ada di dalam perusahaan. Menurut Mukharuddin et al. (2014) hak yang sudah diberikan oleh pemegang saham kepada pihak agen dalam menjalankan usaha, wajib di pertanggungjawabkan kepada pihak pemegang saham dalam bentuk laporan keuangan. Laporan yang disajikan oleh pihak agen atau manajemen merupakan indikator yang digunakan oleh pihak pemegang saham dalam menilai performa pihak manajemen. Ketika pihak pemegang saham merasa performa yang di lakukan kurang memuaskan, maka mereka berhak untuk mengambil keputusan terhadap keberlangsungan pihak manajemen diperusahaan. Konflik kepentingan yang timbul antara pihak manajemen dan pihak pemegang saham dipicu oleh aksi pihak manajemen atau agen yang tidak sesuai dengan keinginan pihak pemegang saham, sehingga membuat timbul biaya keagenan (Mukhtaruddin et al. 2014).

\section{Teori Sinyal}

Latar belakang adanya Signaling Theory adalah karena perusahaan mendapatkan dorongan untuk mengungkapkan informasi baik keuangan ataupun non keuangan kepada pihak eksternal disebabkan adanya asimetri informasi yang terjadi antara pihak manajemen dengan pihak eksternal (Rosiana et al. 2013). Asimetri informasi adalah pengetahuan lebih baik tentang prospek perusahaan yang dimiliki manajer, ketika investor tidak mendapatkan informasi yang sama mengenai prospek perusahaan (Copeland et al. 2005). Sinyal yang diberikan perusahaan untuk mengatasi asimetri informasi salah satunya melalui laporan keuangan. Laporan keuangan dapat memberikan informasi kepada pihak eksternal mengenai kinerja perusahaan secara keseluruhan. Dengan berkurangnya asimetri informasi, maka nilai perusahaan dapat mengalami peningkatan.

Teori sinyal ini muncul ketika informasi keuangan dan ekonomi yang terjadi sekarang di dalam perusahaan dan prospek perusahaan di 
masa depan lebih banyak di ketahui oleh pihak internal seperti direktur dibandingkan dengan investor luar (Meggison 1997). Jika perusahaan mengekspektasikan tingkatan yang lebih tinggi dari pertumbuhan masa depan perusahaan, maka perusahaan akan mencoba untuk memberikan sinyal kepada investor melalui akun yang ada di laporan keuangan (Godfrey et al. 2010).

\section{Kepemilikan Managerial dan Nilai Perusahaan}

Menurut Debby et al. (2014) proporsi kepemilikan saham perusahaan yang sesuai untuk pihak manajemen akan membuat pihak manajemen lebih aktif untuk meningkatkan keuntungan yang akan mereka peroleh dari saham yang dimiliki. Mereka akan meningkatkan keuntungan mereka dengan kata lain mereka juga secara aktif menaikan nilai perusahaan yang tercermin dari nilai saham yang mereka miliki. Kepemilikan manajerial dapat mengenerealisasikan kepentingan pihak manajemen dan pihak pemegang saham sehingga akan menciptakan dampak yang positif dalam meningkatkan nilai perusaahan (Mukhtaruddin et al. 2014). Berdasarkan penjelasan di atas, hipotesis yang diberikan:

$\mathrm{Ha}_{1}$ : Kepemilikan managerial berpengaruh terhadap nilai perusahaan.

\section{Dewan Komisaris Independen dan Nilai Perusahaan}

Dewan Komisaris Independen adalah semua pihak komisaris yang tidak memiliki kepentingan bisnis yang substansial di dalam perusahaan (Wardoyo dan Veronica 2013). Komisaris independen adalah pihak yang ditunjuk memiliki hak dalam rangka pegawasan terhadap tata kelola di dalam perusahaan. Menurut Debby et al. (2014) semakin tinggi proporsi komisaris independen yang ada di perusahaan dapat membuat pihak manajemen bekerja lebih baik, sehingga dapat menciptakan nilai perusahaan yang tinggi. Komisaris independen diharapkan dapat menjalankan tugas dalam memonitor jalannya kegiatan perusahaan serta dapat memberikan saran bagi dewan direksi perusahaan. Berdasarkan penjelasan diatas, hipotesis yang diberikan:

$\mathrm{Ha}_{2}$ : Dewan komisaris independen berpengaruh terhadap nilai perusahaan.

\section{Ukuran Dewan Komisaris dan Nilai Perusahaan}

Pengaruh ukuran dewan komisaris terhadap nilai perusahaan memiliki hasil yang beragam. Besar kecilnya dewan komisaris dapat menjadi faktor penentu dari efektivitas pengawasan terhadap manajemen perusahaan salah satunya didukung dengan penelitian yang dilakukan oleh Rano dan Midiastuty (2011). Ketika manajemen perusahaan mendapatkan pengawasan dan nasihat dari dewan komisaris, dan manajemen bekerja secara efektif maka dapat meningkatkan profit yang diperoleh perusahaan yang berpengaruh terhadap nilai saham yang mencerminkan nilai perusahaan. Berdasarkan penjelasan diatas, hipotesis yang diberikan:

$\mathrm{Ha}_{3}$ : Ukuran dewan komisaris berpengaruh terhadap nilai perusahaan.

\section{Komite Audit dan Nilai Perusahaan}

Menurut Debby et al. (2014) komite audit adalah salah satu komponen baru dalam sistem pengendalian perusahaan yang dipilih, dibentuk dan diberhentikan oleh dewan komisaris. Menurut Mukhtaruddin et al. (2014) ketika komite audit dapat dijalankan dengan baik di dalam perusahaan, maka sudah dapat menerapkan salah satu konsep dasar GCG yakni transparasi. Jika transparasi sudah dapat dicapai maka perusahaan dapat memberikan keyakinan yang memadai kepada para investor maka perusahaan akan menjadi sorotan utama investor dalam pasar modal. Ketika perusahaan sudah menjadi sorotan di pasar modal maka perusahaan menjadi salah satu pertimbangan investor dalam berinvestasi, maka dengan kata lain akan menaikan nilai perusahaan. Hipotesis yang diberikan: 
Has: Komite audit berpengaruh terhadap nilai perusahaan.

\section{Ukuran Perusahaan dan Nilai Perusahaan}

Menurut Siahaan (2013) semakin besar perusahaan maka perusahaan tersebut akan lebih terkenal, maka informasi yang ada di perusahaan pun akan semakin luas diketahui investor. Ketika investor memiliki banyak informasi yang memadai maka akan meningkatkan kepercayaan investor untuk menanamkan dananya ke perusahaan, sehingga nilai perusahaan tersebut pun semakin tinggi. Dengan kata lain semakin besar perusahaan akan membuat sumber pendanaan yang berasal dari eksternal semakin banyak. Menurut Siahaan (2013) total asset yang dimiliki perusahaan besar dapat mencerminkan bahwa perusahaan berada di dalam tahapan yang sudah cukup matang dibandingkan dengan total asset yang dimiliki perusahaan kecil. Ukuran perusahaan merupakan salah satu indikasi mengukur kinerja suatu perusahaan dan ukuran perusahaan yang besar dapat mencerminkan jika perusahaan mempunyai komitmen yang tinggi untuk terus memperbaiki kinerjanya, (Dewi dan Wirajaya 2013). Ketika perusahaan memiiki komitmen yang tinggi untuk kinerja perusahaannya, maka investor mau membayar lebih mahal karena percaya bahwa mereka akan mendapatkan tingkat pengembalian yang tinggi atas biaya yang dibayarkan. Berdasarkan penjelasan diatas, hipotesis yang diberikan:

$\mathrm{Ha}_{5}$ : Ukuran perusahaan berpengaruh terhadap nilai perusahaan.

\section{Return on Equity dan Nilai Perusahaan}

Profitabilitas adalah tingkat laba bersih yang bisa dicapai oleh perusahaan pada saat menjalankan operasional perusahaan (Debby et al.2014). Banyak cara untuk mengukur profitabilitas perusahaan, salah satunya dengan menggunakan return on equity. Return on equity adalah rasio yang digunakan untuk mengukur kemampuan perusahaan dalam menghasilkan laba bersih (yang telah di kurangi pajak dan bunga) untuk mengembalikan ekuitas para pemegang saham. Menurut Sudiani (2015) Return on equity merupakan suatu ukuran yang menggambarkan kemampuan sebuah perusahaan dalam mengelola modal sendiri yang dimilikinya. Perusahaan yang memiliki kemampuan yang baik dalam mengelola modal sendiri yang dimilikinya tentu saja dapat terlihat dari tingkat return atau net income yang perusahaan tersebut peroleh. Sehingga nilai Return on equity yang semakin tinggi akan menunjukkan kemampuan perusahaan yang semakin efektif dan efisien dalam pengelolaan modalnya. Berdasarkan penjelasan diatas, hipotesis yang diberikan:

$\mathrm{Ha}_{6}$ : Return on equity berpengaruh terhadap nilai perusahaan.

\section{Kepemilikan Institusional dan Nilai Perusahaan}

Menurut Abukosim et al. (2014) kepemilikan institusional adalah perusahaan yang bertindak sebagai pihak ketiga untuk menjalankan pengendalian yang lebih profesional atas investasi yang dimiliki di perusahaan dan kepemilikan institusional dapat sebagai alat untuk mencegah perilaku manajemen dalam melakukan Fraud. Semakin tinggi jumlah kepemilikan institusional yang ada didalam perusahaan akan memperkuat adanya pengendalian dari luar perusahaan, (Sakti dan Nugroho 2012). Adanya proporsi kepemilikan institusional dapat menyetarakan kepentingan dari investor institusional (lembaga) dan pemangku kepentingan lainnya. Berdasarkan penjelasan diatas, hipotesis yang diberikan:

$\mathrm{Ha}$ : Kepemilikan institusional berpengaruh terhadap nilai perusahaan.

\section{Leverage dan Nilai Perusahaan}

Dalam Penelitian ini leverage diukur dengan menggunakan debt to equity ratio. Debt to equity ratio merupakan rasio solvabilitas yang menggambarkan kemampuan suatu perusahaan dalam memenuhi kewajiban jangka panjangnya, sehingga bisa melihat tingkat resiko 
tak tertagihnya suatu hutang atau kewajiban. Semakin tinggi debt to equity ratio, maka menandakan struktur permodalan usaha lebih banyak memanfaatkan hutang-hutang relatif terhadap ekuitas (Rompas 2013). Berdasarkan penjelasan diatas, hipotesis yang diberikan:

Ha8: Leverage berpengaruh terhadap nilai perusahaan.

\section{METODA PENELITIAN}

Penelitian ini meneliti dengan menggunakan sampel dari populasi perusahaan non-keuangan yang terdaftar di Bursa Efek Indonesia (BEI) dengan periode penelitian selama 3 tahun, yaitu 2014-2016. Hasil dari proses sampel dengan menggunakan Teknik purposive sampling menghasilkan 82 perusahaan sehingga sample yang digunakan sebanyak 246 data.

Tabel 1: Prosedur Pemilihan Sampel

\begin{tabular}{|c|c|c|c|}
\hline No. & Keterangan & Jumlah & Data \\
\hline 1 & $\begin{array}{l}\text { Perusahaan non keuangan yang terdaftar di Bursa Efek Indonesia } \\
\text { dan mempublikasi laporan keuangan dari tahun 2014-2016. }\end{array}$ & 407 & 1221 \\
\hline 2 & $\begin{array}{l}\text { Perusahaan dengan laporan keuangan yang tidak berakhir pada } \\
\text { tanggal } 31 \text { Desember selama periode tahun 2014-2016. }\end{array}$ & (4) & $(12)$ \\
\hline 3 & $\begin{array}{l}\text { Perusahaan yang tidak menerbitkan laporan keuangan yang } \\
\text { dinyatakan dalam satuan mata uang rupiah. }\end{array}$ & (82) & (246) \\
\hline 4 & $\begin{array}{l}\text { Perusahaan yang tidak memiliki kelengkapan data mengenai } \\
\text { kepemilikan manajerial secara konsisten selama periode 2014-2016. }\end{array}$ & (180) & (540) \\
\hline 5 & $\begin{array}{l}\text { Perusahaan yang tidak memiliki dewan komisaris independen } \\
\text { selama periode } 2014-2016 \text {. }\end{array}$ & (8) & (24) \\
\hline 6 & $\begin{array}{l}\text { Perusahaan yang tidak melaporkan laba bersih secara berturut-turut } \\
\text { selama periode } 2014-2016 \text {. }\end{array}$ & (43) & (129) \\
\hline 7 & $\begin{array}{l}\text { Perusahaan yang tidak memiliki kelengkapan data mengenai } \\
\text { kepemilikan institusional selama periode 2014-2016. }\end{array}$ & (6) & (18) \\
\hline 8 & $\begin{array}{l}\text { Perusahaan yang tidak memiliki kelengkapan data mengenai komite } \\
\text { audit selama periode } 2014-2016 \text {. }\end{array}$ & (2) & (6) \\
\hline \multicolumn{2}{|r|}{$\begin{array}{c}\text { Total perusahaan non keuangan yang digunakan sebagai sampel } \\
\text { penelitian }\end{array}$} & 82 & 246 \\
\hline
\end{tabular}

Nilai Perusahaan diukur menggunakan Tobins-Q. Peneliti menggunakan harga saham sebagai alat ukur nilai perusahaan. Debby et al. (2014) menyatakan nilai perusahaan di rumuskan sebagai berikut:

$$
Q=\frac{M V E+D}{B V E+D}
$$

$\mathrm{Q} \quad=$ Nilai Perusahaan

MVE = Nilai Pasar Ekuitas (Equity Market Value)

BVE = Nilai Buku Ekuitas (Equity Book Value)

D = Nilai buku total Hutang Market Value Equity (MVE) diperoleh dari hasil perkalian harga saham penutupan (closing price) akhir tahun dengan jumlah saham yang beredar (outstanding shares) pada akhir 
tahun. BVE diperoleh dari selisih total aset perusahaan dengan total kewajibannya.

Kepemilikan Manajerial adalah tingkat kepemilikan dari pihak manajemen yang memiliki peran aktif dalam pengambilan keputusan (Mukhtaruddin et al. 2014). Menurut Debby et al. (2014) kepemilikan manajerial diukur dari jumlah kepemilikan saham oleh pihak dewan direksi dan dewan komisaris dalam perusahaan. Data yang digunakan berskala rasio dengan rumus sebagai berikut: $\mathrm{KM}=\Sigma$ Kepemilikan pihak direksi + pihak komisaris.

Dewan Komisaris Independen adalah anggota dewan yang tidak memiliki hubungan istimewa atau berhubungan dengan komisaris lainnya dalam perusahaan (Mukhtaruddin et al. 2014). Variabel independen ini menggunakan data berskala rasio dan rumus menurut Mukhtaruddin et al. (2014): KI = Jumlah anggota dewan komisaris Independen / Total dewan komisaris.

Ukuran Dewan Komisaris memegang peranan penting dalam implementasi dari good corporate governance. Dewan komisaris merupakan tingkat keberhasilan perusahaan karena peranannya dalam memastikan strategi perusahaan, akuntabilitas dan tanggung jawab manajemen dalam meningkatkan efisiensi (Mukhtaruddin et al. 2014). Ukuran dewan komisaris diukur menggunakan skala rasio dengan rumus menurut Mukhtaruddin et al. (2014): Ukuran Dewan Komisaris = Jumlah anggota dewan komisaris.

Komite Audit adalah bagian komite yang didirikan oleh dewan komisaris yang memiliki tugas untuk mengatur jalannya manajemen perusahaan (Debby et al. 2014). Penelitian ini menggunakan data berbentuk rasio dengan rumus dari jurnal Debby et al. (2014) sebagai berikut: Komite audit $=\sum$ Jumlah anggota komite audit.

Ukuran Perusahaan biasanya dikaitkan dengan total penjualan, total asset, rata-rata tingkat penjualan dan rata-rata total asset. Ukuran perusahaan adalah ukuran besar kecilnya suatu perusahaan (Narsa 2012). Semakin besar ukuran perusahaan maka semakin besar pula kewajiban yang ditanggung perusahaan dalam menyampaikan laporan keuangan secara lengkap dan benar. Debby et al. (2014) menyatakan ukuran perusahaan dinilai dengan rumus sebagai berikut: Ukuran Perusahaan $=$ Log (Nilai buku dari total asset).

Retrun on Equity adalah salah satu alat untuk mengukur profitabilitas perusahaan. Profitabilitas adalah tingkat keuntungan bersih yang dapat dicapai perusahaan selama periode operasional perusahaan (Debby et al. 2014). Penelitian menggunakan data berskala rasio dengan pengukuran menurut Debby et al. (2014) sebagai berikut: ROE = Laba bersih setelah pajak / Total ekuitas.

Kepemilikan Institusional berarti pemegang saham perusahaan dimiliki oleh pihak organisasi atau pihak institusi yang terkait. Penelitian ini menggunakan data berskala rasio dengan pengukuran menurut Mukhtaruddin et al. (2014) sebagai berikut: Kepemilikan Institusional $=\sum \%$ kepemilikan saham oleh pihak institusional.

Leverage digunakan untuk melihat seberapa besar perusahaan dalam menggunakan pendanaan hutang yang diperoleh (Thaib dan Taroreh 2015). Leverage dihitung menggunakan rumus debt to equity ratio dengan skala rasio menurut Winarto (2015): DER = Total Kewajiban / Total Ekuitas

\section{HASIL PENELITIAN}

Berikut hasil statistika deskriptif untuk setiap variabel dan pengujian hipotesis dapat dilihat pada tabel berikut: 
Tabel 2: Statistika Deskriptif

\begin{tabular}{llrrrr}
\hline Variabel & n & Minimum & Maksimum & Mean & Std. Deviation \\
\hline Q & 246 & 0.21320 & 11.04060 & 1.59943 & 1.43189 \\
KM & 246 & 0.00006 & 66.40060 & 6.21448 & 12.98349 \\
DKI & 246 & 0.14285 & 1 & 0.38550 & 0.11360 \\
UDK & 246 & 2 & 22 & 4.63000 & 2.53100 \\
KA & 246 & 2 & 6 & 3.15000 & 0.54300 \\
UP & 246 & 11.12640 & 14.41810 & 12.53239 & 0.73662 \\
ROE & 246 & 0.00013 & 0.90890 & 0.12521 & 0.11911 \\
KI & 246 & 7.70450 & 98.48080 & 63.39332 & 19.35004 \\
DER & 246 & 0.00312 & 13.54320 & 1.11909 & 1.59077 \\
\hline
\end{tabular}

Tabel 3: Hasil Uji Regresi Berganda

\begin{tabular}{|c|c|c|}
\hline Variabel & B & Sig. \\
\hline (Constant) & 0.387 & 0.843 \\
\hline KM & -0.004 & 0.627 \\
\hline DKI & 2.131 & 0.008 \\
\hline UDK & 0.131 & 0.001 \\
\hline $\mathrm{KA}$ & -0.080 & 0.631 \\
\hline UP & 0.009 & 0.950 \\
\hline ROE & 3.509 & 0.000 \\
\hline $\mathrm{KI}$ & -0.004 & 0.470 \\
\hline DER & -0.201 & 0.002 \\
\hline
\end{tabular}

Adjusted R 0.142 F 6.072 Sig 0.000

Kepemilikan Managerial (KM) memiliki nilai signifikan sebesar 0.627 lebih besar dari 0.05 sehingga dapat disimpulkan bahwa hipotesis alternatif pertama $\left(\mathrm{Ha}_{1}\right)$ tidak diterima. Hal ini menunjukan bahwa kepemilikan managerial tidak berpengaruh terhadap nilai perusahaan pada perusahaan non keuangan yang terdaftar di Bursa Efek Indonesia. Apabila jumlah dari kepemilikan pihak managerial dirasa kurang signifikan maka keuntungan bagi pihak manajerial pun tidak besar, maka kepemilikan manajerial yang tidak signifikan jumlahnya tidak akan mempengaruhi kinerja dan motivasi manajerial untuk meningkatkan nilai perusahaan.

Dewan Komisaris Independen (DKI) memiliki nilai signifikan sebesar 0.008 lebih kecil dari 0.05 , sehingga dapat disimpulkan bahwa hipotesis alternatif pertama $\left(\mathrm{Ha}_{2}\right)$ diterima. $\mathrm{Hal}$ ini menunjukan bahwa dewan komisaris independen mempengaruhi nilai perusahaan pada perusahaan non keuangan yang terdaftar di Bursa Efek Indonesia. Dewan Komisaris Independen yang merupakan salah satu regulasi dari pemerintah dalam memberikan pengawasan terhadap laporan keuangan. Laporan keuangan yang di awasi akan membuat jalannya operasional di dalam perusahaan menjadi lebih baik dan sesuai dengan standar. Hasil laporan keuangan yang diawasi akan mencerminkan keadaan yang sesungguhnya dari perusahaan, sehingga dapat menimbulkan rasa percaya dari pihak internal dan ekternal 
perusahaan sehingga dapat menaikan nilai dari perusahaan tersebut.

Ukuran Dewan Komisaris (UDK) memiliki nilai signifikan 0.001 lebih kecil dari 0.05 sehingga dapat disimpulkam bahwa hipotesis alternatif pertama $\left(\mathrm{Ha}_{3}\right)$ diterima. Berdasarkan kesimpulan tersebut maka ukuran dewan komisaris berpengaruh terhadap nilai perusahaan. Besar kecilnya jumlah dewan komisaris di dalam perusahaan dapat mempengaruhi efektivitas fungsi dari dewan komisaris. Semakin besar ukuran dewan komisaris di dalam perusahaan maka fungsi pengawasan didalam perusahaan akan semakin baik. Pengawasan dapat membuat kinerja didalam perusahaan semakin baik dan kinerja yang baik akan membuat para pemegang saham menjadi lebih senang dan yakin terhadap perusahaan yang akan berdampak terhadap meningkatnya nilai perusahaan.

Komite Audit (KA) memiliki nilai signifikan 0.631 lebih besar dari 0.05 sehingga dapat disimpulkan bahwa hipotesis alternatif pertama ( $\left.\mathrm{Ha}_{4}\right)$ tidak diterima. Berdasarkan hasil tersebut maka komite audit tidak berpengaruh terhadap nilai perusahaan. Komite audit di dalam perusahaan bertugas untuk mengawasi jalannya pembuatan laporan keuangan sehingga dapat menghindari kecurangan dalam pembuatan laporan keuangan. Namun jumlah komite audit yang kurang signifikan dapat mengurangi efektivitas pengawasan. Kurang maksimalnya komite audit dalam menjalankan tugasnya membuat kualitas dari laporan keuangan yang dihasilkan kurang maksimal sehingga tidak berpengaruh terhadap nilai perusahaan.

Ukuran Perusahaan (UK) memiliki nilai signifikan sebesar 0.950 , dari hasil ini dapat disimpulkan bahwa hipotesis alternatif pertama ( $\left.\mathrm{Ha}_{5}\right)$ tidak diterima. Hal ini berarti bahwa ukuran perusahaan tidak berpengaruh terhadap nilai perusahan non keuangan yang terdaftar di Bursa Efek Indonesia. Ukuran dari perusahaan dapat dilihat dari jumlah aset yang di miliki oleh perusahaan. Namun besar kecilnya jumlah aset yang dimiliki perusahaan tidak akan mempengaruhi jumlah laba yang dapat di hasilkan dari kegiatan operasional perusahaan. Sebesar apapun jumlah aset yang dimiliki perusahaan apabila tidak dapat di gunakan secara optimal tidak dapat meningkatkan nilai perusahaan Sehingga besar kecilnya perusahaan tidak memiliki pengaruh terhadap nilai dari perusahaan.

Return on Equity (ROE) memiliki nilai signifikan sebesar 0.000 lebih kecil dari 0.05 , sehingga dapat disimpulkan bahwa hipotesis alternatif pertama $\left(\mathrm{Ha}_{6}\right)$ diterima. Hasil ini menunjukan bahwa independen ROE berpengaruh terhadap nilai perusahaan. Return on Equity (ROE) adalah tingkat pengembalian atas ekuitas yang di setorkan pihak investor terhadap perusahan. ROE didapatkan dari jumlah laba yang di hasilkan dari perusahaan dibagi total ekuitas perusahaan. Semakin tinggi laba yang dihasilkan perusahaan maka semakin tinggi peningkatkan jumlah pengembalian yang diberikan kepada pemegang saham. Dengan semakin tingginya pengembalian yang diberikan perusahaan akan membuat para pemegang saham berlomba untuk memiliki dan membeli saham perusahaan karena keuntungan yang didapat dari pengembalian, sehingga nilai dari perusahaan akan meningkat di mata para investor.

Kepemilikan Institusional (KI) memiliki nilai signifikan sebesar 0.470 lebih besar dari 0.05 ,sehingga dapat disimpulkan bahwa hipotesis alternatif pertama $\left(\mathrm{Ha}_{7}\right)$ tidak diterima. Hasil tersebut menunjukan kepemilikan institusional tidak berpengaruh terhadap nilai perusahaan. Hal ini dikarenakan jumlah pihak institusional yang memiki perusahaan lewat saham nilainya tidak signifikan sehingga fungsi dari adanya pihak institusional tidak berjalan dengan maksimal, sehingga kepemilikan institusional tidak berpengaruh terhadap nilai perusahaan.

Leverage yang diukur menggunakan DER memiliki nilai signifikan sebesar 0.002 lebih kecil dari 0.05 , sehingga dapat disimpulkan 
bahwa hipotesis alternatif pertama ( $\left.\mathrm{Ha}_{8}\right)$ diterima. Hasil ini menunjukan bahwa leverage berpengaruh negatif terhadap nilai perusahaan. Semakin tingginya leverage perusahaan menandakan komposisi sumber pendanaan perusahaan lebih lebih banyak menggunakan hutang dibandingkan dengan ekuitas. Pemegang saham akan merasa lebih beresiko jika menanamkan uangnya kedalam perusahaan karena jika terjadi likuidasi maka peluang untuk pengembalian atas ekuitas yang diberikan semakin kecil karena harus memberikan kepada pihak kreditor terlebih dahulu, sehingga semakin tinggi leverage perusahaan akan memberikan dampak penurunan terhadap nilai dari perusahaan.

\section{PENUTUP}

Kepemilikan manajerial tidak berpengaruh terhadap nilai perusahaan, hasil ini di dukumg oleh penelitian yang dilakukan oleh Debby et al. (2014), Prastusi dan Budiarsih (2015), serta Abukosim et al. (2014). Dewan komisaris independen berpengaruh terhadap nilai perusahaan, hasil ini didukung oleh penelitian yang dilakukan dengan Rano dan Midiastuti (2011), Muryati dan Suardhika (2014) yang berpendapat bahwa dewan komisaris independen berpengaruh terhadap nilai perusahaan. Ukuran dewan komisaris berpengaruh terhadap nilai perusahaan, hasil ini di dukung oleh penelitian yang dilakukan Siahaan (2013). Komite audit tidak berpengaruh terhadap nilai perusahaan, hasil ini didukung oleh penelitian yang dilakukan Debby et al. (2014), Siahaan (2013), Wardoyo dan Veronica (2013), serta Rano dan Midiastuty (2011).

Ukuran perusahaan tidak berpengaruh terhadap nilai perusahaan, hasil ini didukung oleh penelitian yang dilakukan oleh Dewi dan Wirajaya (2013). Return on equity berpengaruh terhadap nilai perusahaan, hasil ini di dukung oleh penelitian yang dilakukan oleh Debby et al. (2014) yang didukung oleh penelitian Wardoyo dan Veronica (2013) serta Sakti dan Nugroho (2012). Kepemilikan institusional tidak berpengaruh terhadap nilai perusahaan, hasil ini di dukung oleh penelitian yang dilakukan Mukhtaruddin et al. (2014). Leverage yang diukur menggunakan debt equity ratio memiliki hasil berpengaruh negatif terhadap nilai perusahaan, hasil ini didukung penelitian yang dilakukan oleh Bernandhi dan Muid (2014), Kodir (2013) dan Sianturi (2015).

Keterbatasan dari penelitian ini yaitu: terdapat variabel-variabel lain yang dapat memengaruhi nilai perusahaan yang tidak digunakan penulis di dalam penelitian ini sehingga variabel independen yang berpengaruh dalam model penelitian terbatas; data yang diteliti tidak berdistribusi normal walaupun sudah dilakukan uji outlier; terdapat tiga dari delapan variabel independen yang terkena masalah heteroskedastisitas. Dengan adanya keterbatasan yang ada di dalam penelitian ini, rekomendasi untuk penelitian selanjutnya yaitu: menambah variabel independen yang diteliti seperti kebijakan dividen, corporate social responsibility (CSR), profitabilitas, aktivitas perusahaan; melakukan penambahan data dari segi tahun yang diteliti atau bisa menggunakan metode statistik lain seperti mengganti uji parametrik menjadi non parametrik; melakukan transformasi pada variabel yang sedang ditaksir bisa dengan membagi model regresi dengan salah satu variabel independen dan melakukan transformasi log. 


\section{REFERENSI:}

Abukosim. 2014. Ownership Structure and Firm Value: Empirical Study on Indonesia Manufacturing Listed Companies. Jurnal of Arts, Science \& Commerce, Vol. 5, No. 4.

Anzlina, Corry Winda dan Rustam. 2013. Pengaruh tingkat Likuiditas, Solvabilitas, Aktivitas dan Profitabilitas terhadap Nilai Perusahaan pada perusahaan Real Estate dan Property di BEl tahun 2006-2008. Jurnal Ekonomi, Vol. 16, No. 2.

Copeland, Thomas, J. Fred Weston, dan Kuldeep Shastri. 2005. Financial Theory and Corporate Policy. United States of America : Pearson Addison Wesley

Debby, Julia Farah, Mukhtaruddin, Emylia Yuniarti, Dewa Saputra dan Abukosim. 2014. Good Corporate Governance, Company's Characteristics and Firm's Value: Empirical Study of Listed Banking on Indonesian Stock Exchange. GSTF Journal on Business Review (GBR), Vol. 3, No. 4.

Dewi, Ayu Sri Mahatma dan Ary Wirajaya. 2013. Pengaruh Struktur Modal, Profitabilitas, Ukuran Perusahaan pada Nilai Perusahaan. E-Jurnal Akuntansi Universitas Udayana, Vol. 4, No. 2: 358-372

Du, Jinmin, Fei Wu, Xingyun Liang. 2016. Corporate liquidity and firm value: evidence from China's listed firms. SHS Web of Conferences 24, DOI: 10.1051

Godfrey, Jayne Maree, Allan Hodgson, Ann Tarca, Jane Hamilton, Scott Holmes. 2010. Accounting theory. Australia : John Wiley \& Sons Australia, Ltd.

Hidayah, Nurul. 2014. The Effect of Company Characteritic Toward Firm Value in The Property ad Real Estate Company in Indonesia Stock Exchange. International Journal of Business, Economics and Law, Vol. 5.

Jensen, M. C and Meckling, W.H. 1976. Theory of the Firm: Managerial Behavior, Agency Costs and Ownership Structure. Journal of Financial Economics, Oktober, 1976, V. 3, No. 4: 305-360.

Mukhtaruddin, Relasari, Messa Felmania. 2014. Good Corporate Governance Mechanism, Corporate Social Responsibility Disclosure on Firm Value : Empirical Study on Listed Company in Indonesia Stock Exchange. International Journal of Finance \& Accounting Studies, Vol. 2, No 1.

Muryati, Ni Nyoman Tri Sariri dan I Made Sadha Suardhika. 2014. Pengaruh Corporate Governance terhadap Nilai Perusahaan. E-Jurnal Akuntansi Universitas Udayana, Vol. 9, No. 2: 411-429.

Narsa, I Made. 2012. Internet Financial Reporting, Pengungkapan Informasi Website, Luas Lingkup Pelaporan Internet, dan Nilai Perusahaan. Jurnal Ekonomi dan Keuangan, Vol. 18, No. 2.

Ogolmagai, Natalia. 2013. Leverage Pengaruhnya Terhadap Nilai Perusahaan Pada Industri Manufaktur Yang Go Public Di Indonesia. Jurnal EMBA Universitas Sam Ratulangi, Vol 1, No. 3: 81-89.

Prastuti, Ni Ketut Karlina dan I Gusti Ayu Nyoman Budiasih. 2015. Pengaruh Good Corporate Governance pada Nilai Perusahaan dengan moderasi Corporate Social Responsibility. E-Jurnal Akuntansi Universitas Udayana, Vol. 13, No. 1: 114-129.

Rano, Pratana Puspa Mediatuty. 2011. Struktur Kepemilikan, Good Corporate Governance, Investasi dan Nilai Perusahaan, Jurnal Akuntansi, Vol. 1, No.1: 40-66.

Rasyid, Abdul. 2015. Effects of ownership structure, capital structure, profitability, and company's growth towards firm value, International Journal of business and Management Invention, Vol 4, No. 4.

Rizqia, Dwita Ayu, Siti Aisjah, Sumiati. 2013. Effect of Managerial Ownership, Financial Leverage, Profitability, Firm Size, and Investment Opportunity on Dividend Policy and Firm Value. Research Journal of Finance and Accounting. Vol.4, No.11.

Rosiana, Gusti Ayu Made Ervina, Gede Juliarsa, dan Maria M. Ratna Sari. 2013. Pengaruh Pengungkapan CSR Terhadap Nilai Perusahaan dengan Profitabilitas sebagai Variabel Pemoderasi. E-Jurnal Akuntansi Universitas Udayana, Vol. 5, No. 3: 723-738.

Rupilu, Wilsna. 2011. Pengaruh Mekanisme Corporate Governance Terhadap Kualitas Laba dan Nilai Perusahaan pada Perusahaan Manufaktur yang Terdaftar di Bursa Efek Indonesia. Jurnal Akuntansi, Manajemen Bisnis \& Sektor Publik (JAMBSP), Vol. 8, No 1: 101-127.

Sakti, Kaharudinsyah Leon, Penta Nugroho. 2012. Pengaruh Good Corporate Governance terhadap Hubungan antara Kinerja Keuangan dengan Nilai Perusahaan. Jurnal Manajemen, Akuntansi, dan Ekonomi Pembangunan, Vol. 10, № 2. 
Siahaan, Fadjar O.P. 2013. The Effect of Good Corporate Governance Mechanism, Leverage, and Firm Size on Firm Value. GSTF International Journal on Bussiness Review (GBR), Vol. 2, No. 4.

Sudiani, Laela. 2015. Analisis Pengaruh Faktor-Faktor Fundamental Terhadap Kinerja Perusahaan LQ 45. EJurnal Apresiasi Ekonomi Vol. 3, No 2.

Suroto. 2015. Pengaruh Keputusan Investasi, Keputusan Pendanaan dan Kebijakan Dividen terhadap Nilai Perusahaan (Studi Empiris Pada Perusahaan LQ-45 Yang Terdaftar Di Bursa Efek Indonesia Periode Februari 2010-Januari 2015). Jurnal IImiah UNTAG Semarang. Vol. 4 No. 3.

Thaib, Chaidir, dan Rita Taroreh. 2015. Pengaruh Kebijakan Hutang dan Profitabilitas terhadap Kebijakan Dividen (Studi pada Perusahaan Foods and Beverages yang terdaftar di BEI tahun 2010-2014). Jurnal EMBA, Vol. 3, No. $4: 215-225$

Timbuleng, Ferlen, Sientje C. Nangoy, Ivonne S. Saerang. 2015. Pengaruh Faktor Likuiditas, Leverage, NPM dan ROI terhadap Nilai Perusahaan (Studi pada Perusahaan Consumer Goods yang Terdaftar di Bursa Efek Indonesia Periode 2010-2013). Jurnal EMBA, Vol.3, No.2: 546-557.

Wardoyo, Theodora Martina Veronica. 2013. Pengaruh Good Corporate Governance, Corporate Social Responsibility \& Kinerja Keuangan terhadap Nilai Perusahaan. Jurnal Dinamika Manjemen, Vol. 4, No.2: $132-149$

Winarto, Jacinta. 2015. The Determinants of Manufacturer Firm Value in Indonesia Stock Exchange. International Journal of Information, Business and Management, Vol. 7, No.4 
